\title{
Area-based conservation in the twenty-first century
}

https://doi.org/10.1038/s41586-020-2773-z

Received: 13 December 2019

Accepted: 20 August 2020

Published online: 7 October 2020

Check for updates

\author{
Sean L. Maxwell ${ }^{1 凶}$, Victor Cazalis ${ }^{2}$, Nigel Dudley ${ }^{1,3}$, Michael Hoffmann $^{4}$, Ana S. L. Rodrigues ${ }^{2}$, \\ Sue Stolton ${ }^{3}$, Piero Visconti ${ }^{5,6,7}$, Stephen Woodley ${ }^{8}$, Naomi Kingston ${ }^{9}$, Edward Lewis ${ }^{9}$, \\ Martine Maron', Bernardo B. N. Strassburg ${ }^{10,11,12}$, Amelia Wenger ${ }^{1,13}$, Harry D. Jonas ${ }^{8,14}$, \\ Oscar Venter ${ }^{15}$ \& James E. M. Watson ${ }^{1,16}$
}

\begin{abstract}
Humanity will soon define a new era for nature-one that seeks to transform decades of underwhelming responses to the global biodiversity crisis. Area-based conservation efforts, which include both protected areas and other effective area-based conservation measures, are likely to extend and diversify. However, persistent shortfalls in ecological representation and management effectiveness diminish the potential role of area-based conservation in stemming biodiversity loss. Here we show how the expansion of protected areas by national governments since 2010 has had limited success in increasing the coverage across different elements of biodiversity (ecoregions, 12,056 threatened species, 'Key Biodiversity Areas' and wilderness areas) and ecosystem services (productive fisheries, and carbon services on land and sea). To be more successful after 2020, area-based conservation must contribute more effectively to meeting global biodiversity goals-ranging from preventing extinctions to retaining the most-intact ecosystems-and must better collaborate with the many Indigenous peoples, community groups and private initiatives that are central to the successful conservation of biodiversity. The long-term success of area-based conservation requires parties to the Convention on Biological Diversity to secure adequate financing, plan for climate change and make biodiversity conservation a far stronger part of land, water and sea management policies.
\end{abstract}

Governments, policy-makers and many members of the conservation community have long held that protected areas are a fundamental cornerstone of biodiversity conservation ${ }^{1,2}$. The importance of other effective area-based conservation measures (OECMs) is also beginning to be recognized ${ }^{3,4}$. OECMs were defined by the Convention on Biological Diversity (CBD) in 2018 as places outside the protected-area estate that deliver effective biodiversity conservation, such as government-run water catchment areas, territories conserved by Indigenous peoples and local communities, as well as some private conservation initiatives (Box 1). Both protected areas and OECMs (here referred to collectively as area-based conservation measures) are acknowledged in the CBD and the 2030 Agenda for Sustainable Development ${ }^{5}$. In particular, the current ten-year Strategic Plan for Biodiversity ${ }^{6}$ of the CBD-which was agreed to by 168 countries in 2010-has an explicit target (Aichi Target 11) that stipulates 'at least 17 per cent of terrestrial and inland water areas and 10 per cent of coastal and marine areas, especially areas of particular importance for biodiversity and ecosystem services, are conserved through effectively and equitably managed, ecologically representative and well-connected systems of protected areas and OECMs, and integrated into the wider landscape and seascape' by 2020. This target has dominated the area-based conservation agenda for the past decade.

Between 2010 and 2019, protected areas expanded from covering $14.1 \%$ to $15.3 \%$ of global land and freshwater environments (excluding Antarctica) and from $2.9 \%$ to $7.5 \%$ of the marine realm ${ }^{7}$ (Figs. 1, 2). Although it is not yet possible to track their global extent systematically, OECMs have emerged as a category of area-based conservation since $2010^{8}$. However, despite these encouraging efforts, some disconcerting spatial dynamics in the global protected-area estate are becoming more apparent. One recent analysis showed that, on average, 1.1 million $\mathrm{km}^{2}$ of land and sea were recorded as being removed from the global protected-area estate annually between 2006 and $2018^{9}$. There is also

${ }^{1}$ Centre for Biodiversity and Conservation Science, School of Earth and Environmental Sciences, University of Queensland, St Lucia, Queensland, Australia. ${ }^{2} \mathrm{CEFE}$, Univ Montpellier, CNRS, EPHE, IRD, Univ Paul Valéry Montpellier 3, Montpellier, France. ${ }^{3}$ Equilibrium Research, Bristol, UK. ${ }^{4}$ Conservation and Policy, Zoological Society of London, London, UK. ${ }^{5}$ Institute of Zoology, Zoological Society of London, London, UK. ${ }^{6}$ Centre for Biodiversity and Environment Research, University College London, London, UK. ${ }^{7}$ International Institute for Applied Systems Analysis (IIASA), Laxenburg, Austria. ${ }^{8}$ World Commission on Protected Areas, International Union for Conservation of Nature, Gland, Switzerland. ${ }^{9}$ UN Environment Programme World Conservation

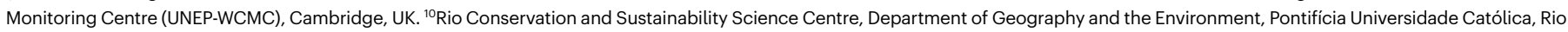
de Janeiro, Brazil. "International Institute for Sustainability, Rio de Janeiro, Brazil. ${ }^{12}$ Programa de Pós Graduacão em Ecologia, Universidade Federal do Rio de Janeiro, Rio de Janeiro, Brazil. ${ }^{13}$ Global Marine Program, Wildlife Conservation Society, New York, NY, USA. ${ }^{14}$ Future Law, Kota Kinabalu, Malaysia. ${ }^{15}$ Ecosystem Science and Management, University of Northern British Columbia, Prince George, British Columbia, Canada. ${ }^{16}$ Global Conservation Program, Wildlife Conservation Society, New York, NY, USA.

凶e-mail: smaxwell@uq.edu.au 


\section{Review}

\section{Box 1}

\section{Protected areas and OECMs are complementary area-based conservation measures}

A protected area is formally defined as "A clearly defined geographical space, recognised, dedicated and managed, through legal or other effective means, to achieve the long term conservation of nature with associated ecosystem services and cultural values"2; an OECM is defined as "A geographically defined area other than a Protected Area, which is governed and managed in ways that achieve positive and sustained long-term outcomes for the in situ conservation of biodiversity, with associated ecosystem functions and services and, where applicable, cultural, spiritual, socioeconomic, and other locally relevant values" ${ }^{\prime \prime 9}$. The feature that distinguishes between a protected area and an OECM is that the former has a primary conservation objective whereas the latter delivers the effective in situ conservation of biodiversity, regardless of its objectives. Protected areas help to conserve critically endangered species such as the Philippine eagle (Pithecophaga jefferyi) (photograph credit: B. Demeulemeester) (a) and the Nassau grouper (Epinephelus striatus) (photograph credit: E. Poliakoff) (b). OECMs have been recognized at a locally managed marine area on Totoya Island (Fiji) (photograph credit: S. Jupiter) (c) and at a conservation concession in Loreto region (Peru) (photograph credit: Brian Moriarty/CC-BY) (d).
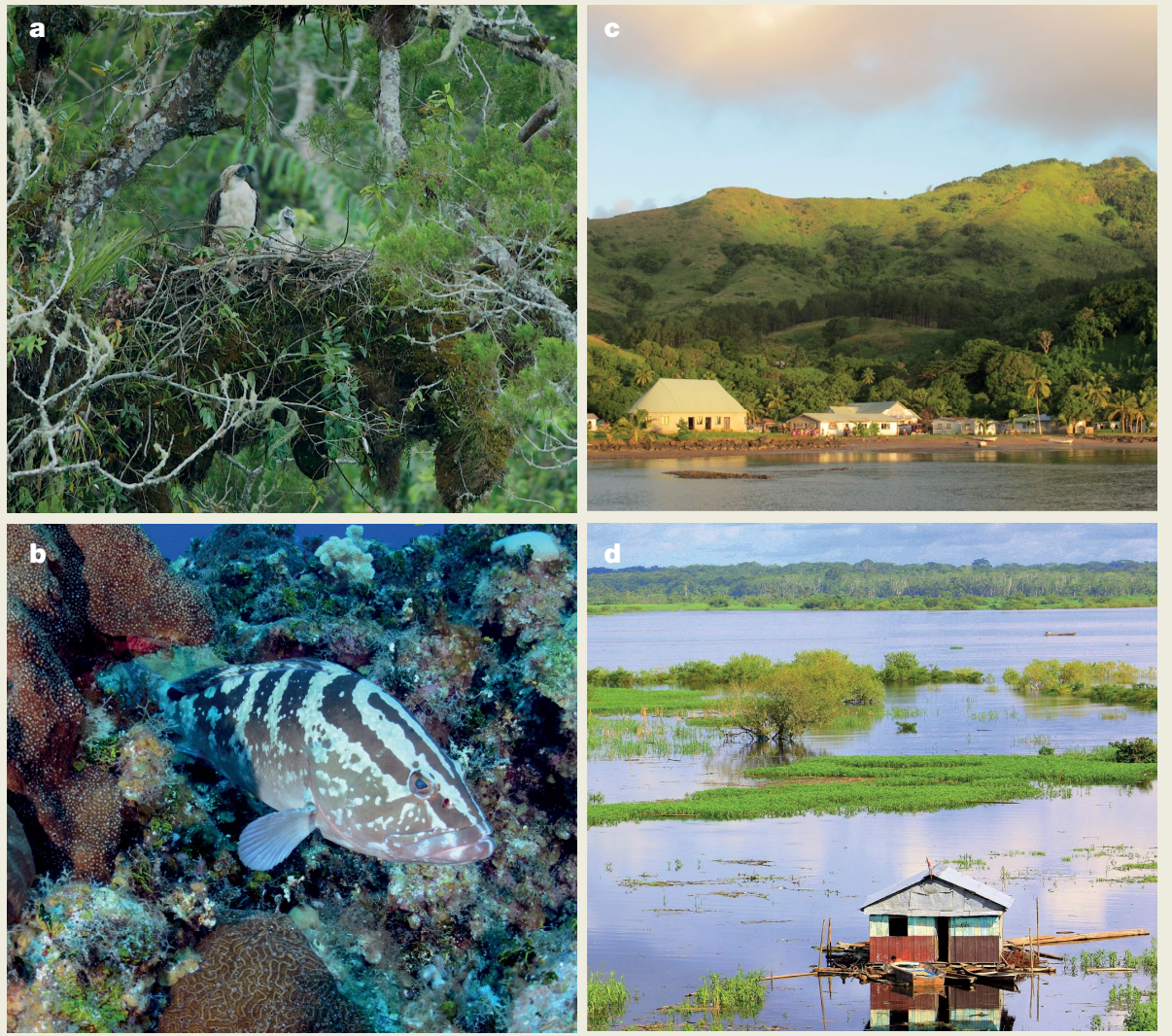

substantial expansion of area-based conservation globally ${ }^{25-28}$ and fundamental changes in how environmental targets are framed and implemented $^{17,22,29,30}$. It is therefore timely to assess the achievements and failures of area-based conservation efforts over the past decade, and to place these findings within the wider context of the global biodiversity crisis.

\section{The performance of protected areas since 2010}

Here we provide an up-to-date temporal analysis (spanning between 2010 and 2019) of how the recent expansion of protected areas globally has affected the net coverage of the qualitative components of Aichi Target 11; details of methodology and calculations are provided in the Supplementary Methods. We omit reference to OECMs in this 


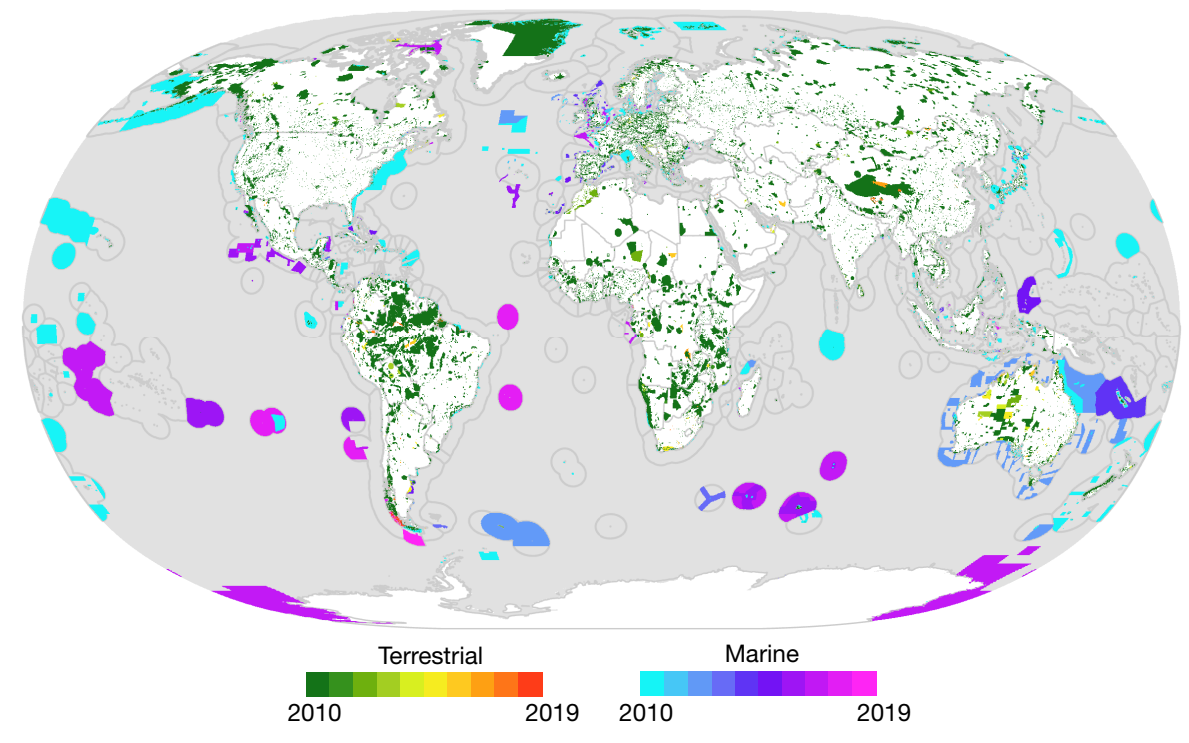

Fig. 1 Mapping the expansion of the global protected-area estate between 2010 and 2019. The map shows the annual expansion of protected areas across marine (blue-to-pink colours) and terrestrial (green-to-red colours) realms on Earth. Protected area data were sourced from ref. ${ }^{7}$. Country borders were

section, as a database showing the global extent of these sites is not yet available.

\section{Protected areas being ecologically representative}

The concept of being ecologically representative has been interpreted as the coverage of species or ecoregions (areas that contain geographically distinct assemblages of species ${ }^{31,32}$ ), especially those that are threatened with extinction ${ }^{10,13,33,34}$. We analysed how expansion of the global protected-area estate between 2010 and 2019 affected coverage of 12,056 species listed as 'Vulnerable', 'Endangered' or 'Critically Endangered' (hereafter referred to as threatened species) on the International Union for Conservation of Nature (IUCN) Red List ${ }^{35}$ (Fig. 3). Between 2010 and 2019, the percentage of species with some portion of their geographical range protected increased from $86 \%$ to $87.6 \%$ $(n=10,563)$. However, only $21.7 \%(n=2,618)$ of species assessed had adequate representation inside protected areas in 2019 (up from $18.9 \%$ in 2010), where adequacy targets for individual species were set according to their geographical range $\mathrm{e}^{34}$.

The proportion of threatened reef-forming corals with adequate representation grew rapidly over the past decade, from $9.1 \%$ to $44.0 \%$. The proportion of species with adequate coverage also increased for threatened mangroves (to 50.0\%), seagrasses (to 50.0\%), marine mammals (to 43.2\%), marine bony fishes (to 42.1\%) and cartilaginous fishes (to $32.4 \%$ ) over this period. However, no threatened marine reptiles had adequate levels of protection in 2019. On land, the proportion of species with adequate coverage grew by $<3 \%$ for birds (to $33.6 \%$ ) and $<2 \%$ for amphibians (to 10.9\%), reptiles (to $13.6 \%$ ), mammals (to $37.0 \%$ ) and freshwater species (to $19.0 \%$ ) in the past decade (Supplementary Tables 1,2$)$. It remains that $78.3 \%(n=9,438)$ of all threatened species assessed had inadequate protection as of 2019, with at least $1,493(12.4 \%)$ remaining without any coverage at all.

We further assessed progress towards the adequacy targets of $17 \%$ protection for terrestrial ecoregions and $10 \%$ for marine ecoregions or pelagic regions. We found that $42.6 \%(n=361)$ of terrestrial ecoregions were adequately protected in 2019 (up from $38.8 \%$ in 2010) (Fig. 3, Supplementary Table 3). We also found that one-fifth (20.6\%) of land protected since 2010 covered tropical and subtropical grassland ecoregions-a critically endangered biome ${ }^{31}$ (Supplementary Table 4). However, $32.9 \%$ of land protected since 2010 covered dry or desert ecoregions, which are relatively species-poor and are well-represented

sourced from the Database of Global Administrative Areas (www.gadm.org). Exclusive economic zones were sourced from Flanders Marine Institute (www.marineregions.org).

in the global protected-area estate ${ }^{31}$. The percentage of marine ecoregions with adequate coverage increased to $45.7 \%(n=106)$ over the past decade (from $31.8 \%$ in 2010) (Supplementary Table 5), with much of this growth occurring in the Southern Ocean around Antarctica ( 0.7 million $\mathrm{km}^{2} ; 4.2 \%$ of all new marine protected area). Despite attracting $81.3 \%$ (14.7 million $\mathrm{km}^{2}$ ) of all new protected areas since 2010 , the coverage in pelagic regions remains low: only $10.8 \%(n=4)$ of these regions were adequately protected in 2019 (up from 2.7\% in 2010) (Fig.3, Supplementary Table 6). The expansion of protected areas in pelagic regions was particularly concentrated in waters between Australia and South America, which received $36.6 \%$ of all new marine protected area $\left(6.0\right.$ million $\left.\mathrm{km}^{2}\right)$ in the past decade.

\section{Coverage of areas of particular importance for biodiversity}

The 'Key Biodiversity Area' (KBA) approach ${ }^{36}$ offers a global standard for identifying marine, terrestrial and freshwater sites that contribute substantially to the global persistence of biodiversity. Over 15,000 KBAs have so far been identified (83.1\% of which are 'Important Bird Areas', the avian subset of KBAs) ${ }^{37}$. Host nations are encouraged to ensure that these sites are managed in ways that ensure the persistence of biodiversity, although this does not necessarily mean inclusion within a protected area $^{36}$. Our analysis showed average coverage of terrestrial KBAs was $45.9 \%$ in 2019 (up from $43.6 \%$ in 2010 ) and $43.3 \%$ for marine KBAs (up from $37.9 \%$ in 2010) (Fig. 3). Overall, around 4,900 KBAs (33.0\%) remained without protected area coverage in 2019.

Wilderness areas are ecologically intact land and seascapes that are predominantly free of human-driven biophysical disturbance ${ }^{38,39}$. They underpin planetary life-support systems $\mathrm{s}^{40}$ and are critical for the long-term persistence of imperilled species ${ }^{41}$, especially in a time of climate change ${ }^{42}$. Over half (55.6\%) of all wilderness overlaps with the geographical range of at least one threatened species, yet wilderness areas are also very spatially discordant from KBAs-only $1.2 \%$ of all land and sea on Earth is simultaneously recognized as both a KBA and a wilderness area (Supplementary Fig. 1). Our analysis shows that coverage increased for both terrestrial (from 19.7\% to 22.1\%) and marine wilderness (2.0\% to $8.5 \%$ ) areas during the past decade (Fig. 3 ).

\section{Coverage of ecosystem services}

The carbon sequestered and stored in terrestrial ecosystems has a pivotal role in mitigating anthropogenic climate change ${ }^{43}$. We therefore 


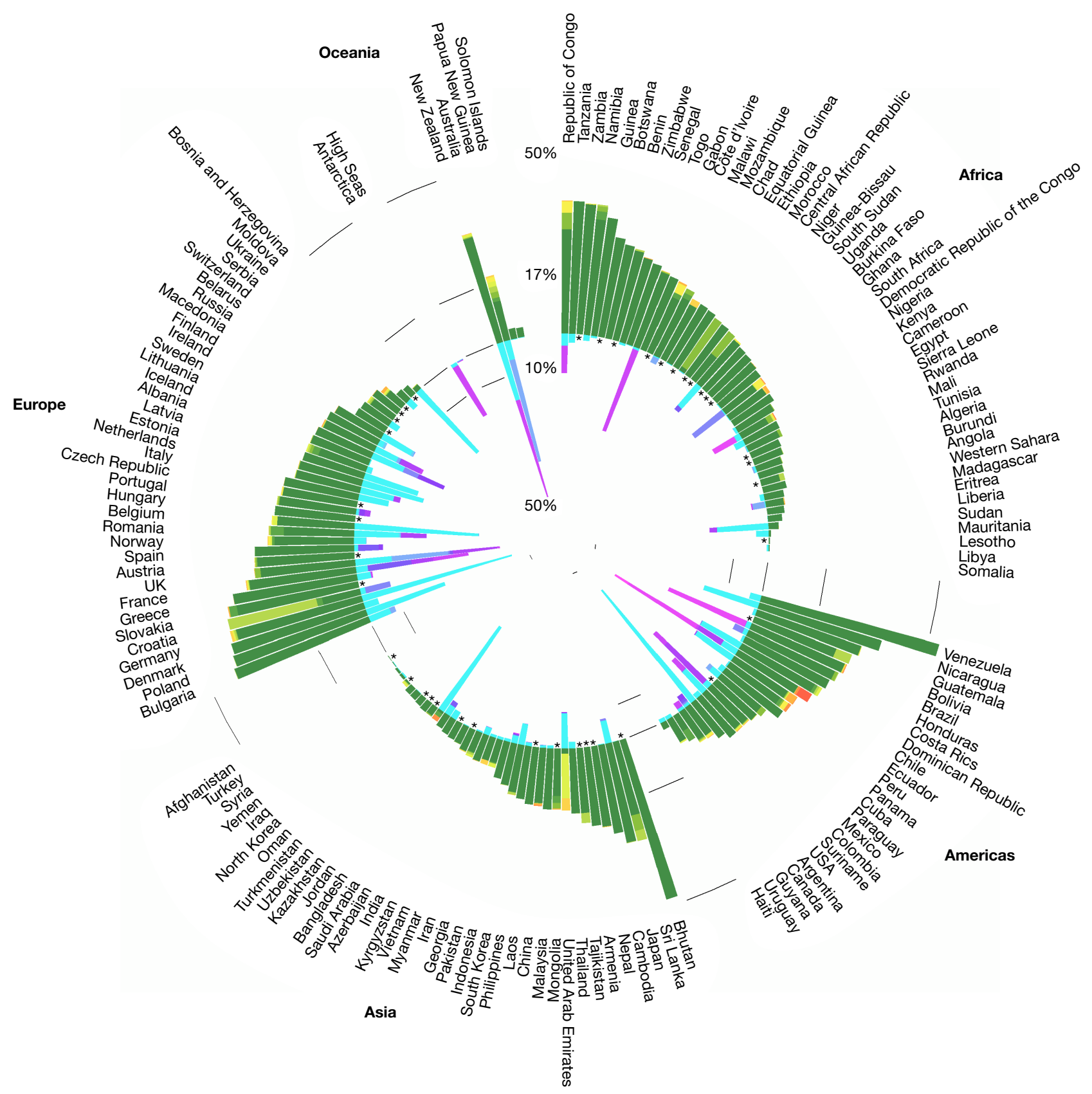

Fig. 2 | Growth of global protected-area estate between 2010 and 2019. Circular plot shows increases in areal coverage (\%) per year for marine and terrestrial protected-area estates for countries $>25,000 \mathrm{~km}^{2}$ in size.

Landlocked countries are marked with an asterisk. Progress towards the

assessed the coverage of global aboveground biomass and soil carbon stocks $^{44}$. Coverage of aboveground biomass increased from $22.6 \%$ in 2010 to $23.7 \%$ (99.0 petagrams of carbon (Pg C)) in 2019. Coverage of global soil-carbon stocks was lower on average and increased less in the past decade, from $13.9 \%$ in 2010 to $14.6 \%$ (400.5 Pg C) in 2019. Large unprotected repositories of soil carbon are prevalent across northeast North America, Russia and southeast Asia (Supplementary Fig. 2). However, maps of terrestrial organic carbon-particularly in peatlands and tropical rainforests-are continually being refined ${ }^{45}$, which may influence future understandings of carbon storage in particular areas.

The 'biological pump' - carbon fixed by phytoplankton in the oceans being exported to the deep ocean ${ }^{46,47}$-also has a key role in mitigating climate change, because it removes carbon from the ocean and atmosphere systems for decades to millennia ${ }^{48}$. We estimate that $0.21 \mathrm{Pg}$ of globally agreed target-to have $17 \%$ of land and inland waters, and $10 \%$ of coastal and marine areas, protected by 2020 -is promising but incomplete. Colours of the bars are as in Fig. 1. Protected area data were sourced from ref. ${ }^{7}$.

particulate organic carbon ${ }^{49}$ and $0.17 \mathrm{Pg}$ of dissolved organic carbon ${ }^{50}$ is exported inside marine protected areas each year (Supplementary Tables 7,8). However, the factors that drive carbon export in the oceans vary seasonally ${ }^{51}$ and the relative value of marine protected areas in carbon export may vary through time.

About three billion people rely on wild-caught or farmed seafood as their primary source of protein, which makes the sustained provision of seafood a globally important goal ${ }^{5}$. We compared protected area coverage of the most- and least-productive marine regions for fisheries catch in the oceans, finding that coverage of the least-productive exclusive economic zones (those within the bottom $20 \%$ for annual fisheries catch per unit area) (Supplementary Table 9) was-on averagethree times greater than coverage of the most-productive exclusive economic zones (those within the top $20 \%$ for annual fisheries catch 

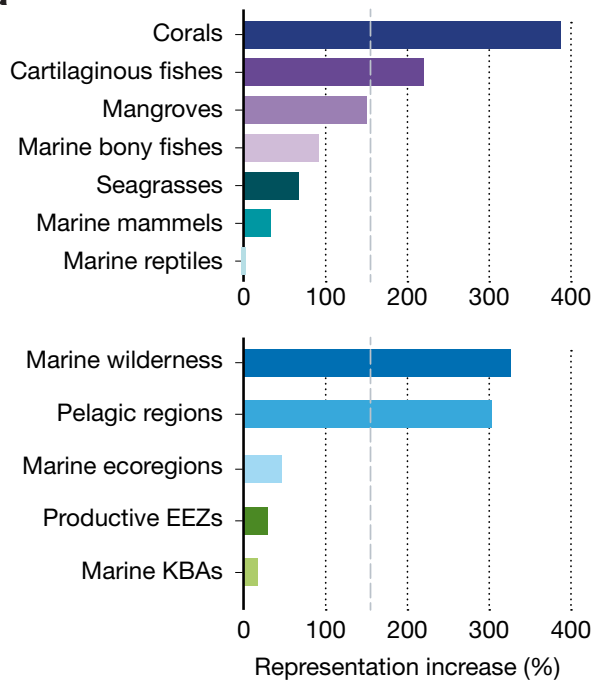

b
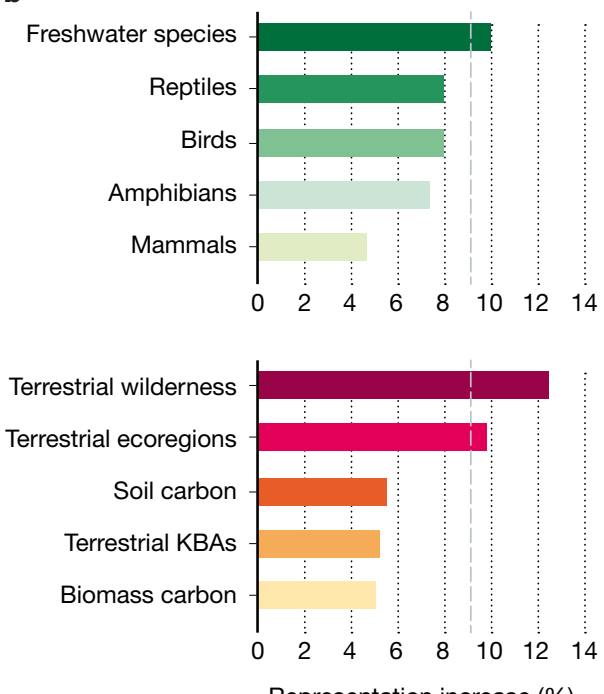

Fig. 3 | Temporal trends in biodiversity and ecosystem service representation within the global marine and terrestrial protected-area estates. a, b, Trends in biodiversity and ecosystem service representation within the global marine (a) and terrestrial (b) protected-area estates. Left, plots showing increases in representation of values (coloured bars) compared with per cent growth in protected-area estates between 2010 and 2019 (grey dashed lines). Coloured bars that extend past the grey dashed lines highlight cases in which when an increase in representation was greater than the growth in the protected-area estate, which suggests that these values benefitted most from the recent expansion of area-based conservation efforts. Right, plots showing change in biodiversity and ecosystem service representation

per unit area) (Supplementary Table 10) (31.2\% versus 9.8\%). Moreover, average coverage of the most-productive exclusive economic zones has not changed notably since 2010 (Fig. 3). We also found that the seven most-productive pelagic regions for fisheries catch have no formal protected area coverage (Supplementary Table 11).

\section{Protected areas being well-connected}

Well-connected ecosystems are critical for maintaining important ecological and evolutionary processes (including species migration and gene flow), especially when species face rapid climatic and environmental changes ${ }^{52,53}$. Connectivity among marine protected areas further helps to replenish and maintain fish populations, including on fished reefs ${ }^{54,55}$. A previous study showed that in 2016 only $30 \%$ of
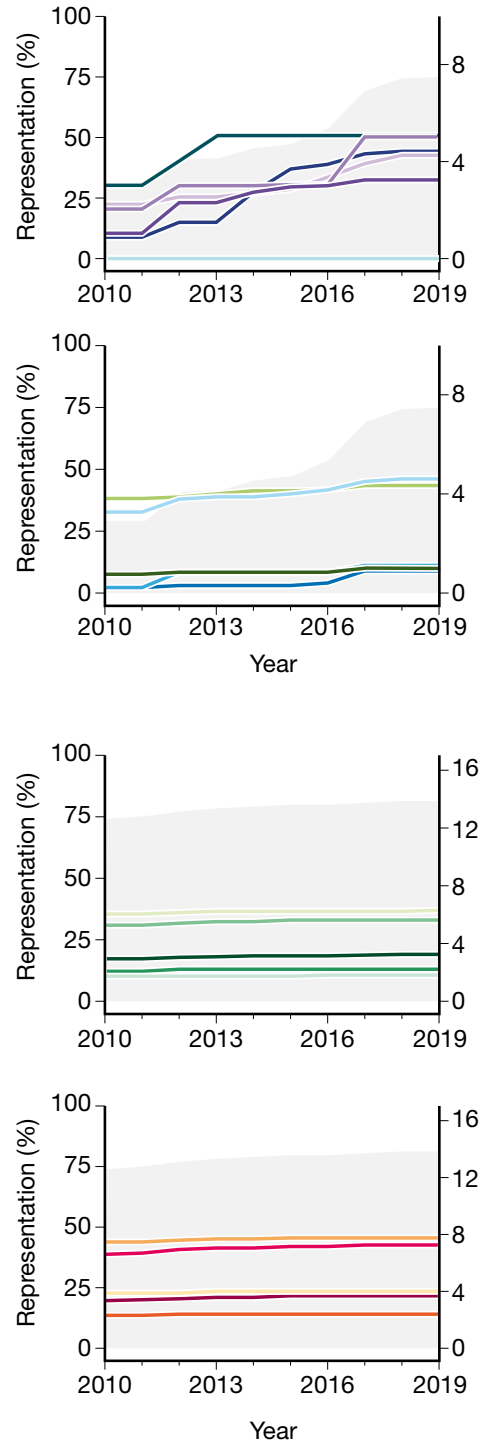

(coloured lines; left axis) as the terrestrial and marine protected-area estates expanded between 2010 and 2019 (grey shading; right axis). For taxonomic groups, trend lines show the proportion of threatened species with adequate representation. Trend lines for ecoregions and pelagic regions show the proportion of these features that are at least $17 \%$ protected (for terrestrial ecoregions) or at least $10 \%$ protected (for marine ecoregions or pelagic regions). Trend lines for all other values, including KBAs, wilderness areas, biomass carbon, soil carbon and exclusive economic zones (EEZs) within the top $20 \%$ for annual fisheries catch per $\mathrm{km}^{2}$, represent global averages. Data sources and methods are provided in the Supplementary Information.

terrestrial ecoregions were at least $17 \%$ covered by protected areas that were within the potential dispersal distance of terrestrial vertebrates ${ }^{56}$. A subsequent study showed that the percentage of connected terrestrial protected areas increased from $6.5 \%$ to $7.7 \%$ between 2010 and $2018^{57}$. However, these assessments did not account for the permeability of unprotected land between protected areas. There have been no global-scale assessments of connectivity among marine or freshwater protected areas, but regional-scale studies show them to have limited connectivity-especially for species with a dispersive larval stage ${ }^{58}$.

\section{Effectiveness of protected area management}

Over the past few decades, four broad approaches have been used to evaluate area-based conservation efforts (Table 1). Three of these 


\section{Review}

Table 1| Approaches for evaluating area-based conservation

\begin{tabular}{|c|c|c|c|}
\hline Type & What is measured & Strengths (+) and weaknesses (-) & Examples \\
\hline $\begin{array}{l}\text { Design } \\
\text { evaluation }\end{array}$ & $\begin{array}{l}\text { Coverage of species } \\
\text { Coverage of ecoregions } \\
\text { Coverage of important areas for } \\
\text { biodiversity and ecosystem services } \\
\text { Protected area connectivity }\end{array}$ & $\begin{array}{l}\text { +Broad spatial data on environmental variables readily available } \\
\text { +Robust methods to identify whether siting decisions for area-based conservation are } \\
\text { influenced by competing interests (for example, agricultural suitability) } \\
\text { +Can include traditional ecological knowledge where available } \\
\text {-Coarse scale assessments might not be adequate for local planning } \\
\text {-Subject to inaccuracies in global datasets }\end{array}$ & Refs. ${ }^{10,11}$ \\
\hline $\begin{array}{l}\text { Input } \\
\text { evaluation }\end{array}$ & $\begin{array}{l}\text { Budget shortfalls } \\
\text { Capacity shortfalls } \\
\text { Social equity shortfalls }\end{array}$ & $\begin{array}{l}\text { +Global database established } \\
\text { +Assessment frameworks that can be conducted rapidly } \\
\text {-Taxonomic or geographical biases in datasets }\end{array}$ & Refs. ${ }^{18,21}$ \\
\hline $\begin{array}{l}\text { Threat } \\
\text { reduction } \\
\text { evaluation }\end{array}$ & $\begin{array}{l}\text { Change in human pressures } \\
\text { Change in environmental state (for } \\
\text { example, pollution, forest cover) }\end{array}$ & $\begin{array}{l}\text { +Human pressures are often useful proxies for broad-scale biodiversity impacts } \\
\text { +Cheap and non-invasive (for example, derived from satellites) } \\
\text {-Often miss important drivers of biodiversity loss (for example, disease, pollution or } \\
\text { poaching) } \\
\text {-Do not always explain local or regional biodiversity patterns }\end{array}$ & Refs. ${ }^{20,60,105}$ \\
\hline $\begin{array}{l}\text { Outcome } \\
\text { evaluation }\end{array}$ & $\begin{array}{l}\text { Species abundance and richness } \\
\text { Extinction risk } \\
\text { Socio-economic outcomes }\end{array}$ & $\begin{array}{l}\text { +Account for what would have happened in the absence of conservation intervention } \\
\text { +Provides the most robust foundation for decision-making } \\
\text {-Counterfactual studies can exclude sites that are small, surrounded by other conservation } \\
\text { interventions or do not have an biophysically similar site that is unprotected for outcome } \\
\text { evaluation } \\
\text {-Data to quantify progress towards goals of area-based conservation (for example, avoiding } \\
\text { extinctions) in the absence of conservation action are often unavailable }\end{array}$ & Refs. ${ }^{20,86,151}$ \\
\hline
\end{tabular}

The different approaches imply different measurements and are subject to strengths and weaknesses. Design, input and threat reduction evaluations all measure means to an end, whereas

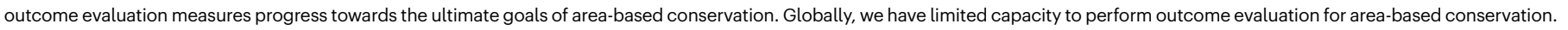

approaches pertain to management effectiveness, the first of which (which we term input evaluation) evaluates the adequacy of management resources for area-based conservation. A recent study of about $23 \%$ of terrestrial protected area found that $47 \%$ of protected areas suffer from inadequate staff and budget resources, with poor resourcing especially noticeable in the Neotropics ${ }^{21}$. Similarly, a study of 433 marine protected areas showed $65 \%$ to have insufficient budget for basic management needs and $91 \%$ to have on-site staff capacity that is inadequate or below optimum ${ }^{20}$. Related inputs, including the weak enforcement of protected area regulation ${ }^{59}$, have also been implicated in poor management effectiveness.

A second evaluation approach (which we term threat reduction evaluation) asks whether area-based conservation effectively reduces threats to the persistence of biodiversity. The majority of these evaluations show that protected areas slow, but do not completely halt, human pressures within their borders. For example, human pressures increased inside $55 \%$ of protected areas on land between 1993 and $2009^{60}$, and in the marine realm $94 \%$ of protected areas created before 2014 permit fishing activities ${ }^{61,62}$. However, terrestrial protected areas have been found to reduce rates of deforestation and forest degradation to below those observed in nearby unprotected areas ${ }^{63}$, including in the Amazon $^{64,65}$; marine protected areas can reduce fishing vessel traffic $^{66}$ and the negative effects of some non-native species ${ }^{67}$.

The third evaluation approach (which we term outcome evaluation) asks whether the goals of area-based conservation are being achieved relative to no intervention taking place. A recent controlled study showed that around 12,000 protected areas were ineffective at reducing human pressures inside their borders between 1995 and $2010^{68}$. However, several studies have reported beneficial effects of protected areas on biodiversity. For example, a controlled study of 359 terrestrial protected areas showed species richness to be $10.6 \%$ higher and abundance $14.5 \%$ higher inside protected areas than outside, with the effects of protection being most prominent in human-dominated land uses in the tropics (for example, cropland and plantations) ${ }^{69}$. Similarly, a controlled study of 218 marine protected areas found that, on average, fish biomass inside protected areas is nearly double that in non-protected sites $^{20}$. Marine protected areas can also promote the recovery of commercial fish species ${ }^{70,71}$. In particular, no-take marine reserves can effectively increase species richness, density and biomass in both tropical and temperate systems ${ }^{20,72-74}$, as well as being effective at restoring trophic function ${ }^{75,76}$ and lowering levels of coral disease ${ }^{77}$. Finally, several studies have reported on the social effects of protected areas. For example, a controlled study covering 603 protected areas found that households near protected areas with tourism opportunities had higher wealth levels (by 17\%) and a lower likelihood of poverty (by 16\%) than similar households living far from

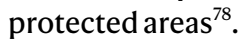

\section{Equitable governance and management in protected areas}

Social equity in the context of protected areas has multiple dimensions, including distributional equity (for example, people agree on a scheme for sharing benefits and burdens), procedural equity (for example, decision-making that is transparent, accountable and participatory) and recognition (for example, respect for cultural identities, customary rights and traditional management practices) ${ }^{79}$. A recent survey covering 225 protected areas showed the majority of conservation managers, staff and community representatives believe that the benefits of protected areas are shared equally ${ }^{15}$. Yet, the study also showed that decision-making was not equitable in many cases and that local stakeholders perceived a general loss of rights over natural resources after the establishment of a protected area ${ }^{15}$.

Despite limited evidence of progress towards social equity, protected areas that do integrate local communities as stakeholders often produce better socio-economic and conservation outcomes ${ }^{14,80}$. A review of 27 marine protected areas found that stakeholder engagement, surveillance, leadership, political will and the existence of sanctioning and conflict resolution mechanisms were key factors in achieving ecological objectives $^{81}$. No-take, well-enforced and longer-established marine protected areas show not only conservation success ${ }^{82}$, but also positive economic and governance outcomes for dependant human communities $^{83}$. Furthermore, community-managed terrestrial protected areas are often more effective than nationally designated protected areas at reducing deforestation pressures, including in Peru, Brazil, Australia and Namibia ${ }^{84,85}$.

\section{Lessons learned and priority actions}

Collectively, national governments have made some progress towards Aichi Target 11 in the past decade-particularly in the marine realm. However, it is clear that nations have, as yet, failed to meet this target. The rate of expansion of terrestrial protected areas needed to be double what was observed in the past decade to achieve $17 \%$ coverage for land 
Table 2 | Synthesis of current progress towards targets for area-based conservation

\begin{tabular}{|c|c|c|c|c|}
\hline \multirow{2}{*}{$\begin{array}{l}\text { Global targets for area-based } \\
\text { conservation }\end{array}$} & \multicolumn{4}{|c|}{ Progress } \\
\hline & Good & Moderate & Poor & Unknown \\
\hline \multicolumn{5}{|l|}{ To conserve: } \\
\hline - $17 \%$ of terrestrial and inland water & \multicolumn{4}{|c|}{$\mathrm{X}$} \\
\hline - $10 \%$ of coastal and marine areas & \multicolumn{4}{|c|}{$X$} \\
\hline \multicolumn{5}{|l|}{$\begin{array}{l}\text { To capture important places for } \\
\text { biodiversity and ecosystem services, } \\
\text { such as: }\end{array}$} \\
\hline - KBAs & \multicolumn{4}{|c|}{$x$} \\
\hline -Wilderness areas & \multicolumn{4}{|c|}{$x$} \\
\hline \multicolumn{5}{|l|}{ To be effectively managed by: } \\
\hline - Having adequate resources & \multicolumn{4}{|c|}{$\mathrm{X}$} \\
\hline - Abating human pressures & \multicolumn{4}{|c|}{$x$} \\
\hline \multicolumn{4}{|l|}{ - Having positive biodiversity outcomes } & $x$ \\
\hline To be equitably managed & \multicolumn{4}{|c|}{$\mathrm{X}$} \\
\hline \multicolumn{5}{|l|}{ To be ecologically representative by: } \\
\hline $\begin{array}{l}\text { - Covering } 17 \% \text { of all terrestrial } \\
\text { ecoregions }\end{array}$ & \multicolumn{4}{|c|}{$\mathrm{X}$} \\
\hline - Covering $10 \%$ of all marine ecoregions & \multicolumn{4}{|c|}{$\mathrm{X}$} \\
\hline - Covering $10 \%$ of all pelagic regions & \multicolumn{4}{|c|}{$\mathrm{x}$} \\
\hline To be well-connected and integrated & \multicolumn{4}{|c|}{$x$} \\
\hline \multicolumn{5}{|c|}{$\begin{array}{l}\text { Progress towards targets is assessed as good (substantial positive trends at a global scale } \\
\text { relating to most aspects of the element); moderate (the overall global trend is positive but } \\
\text { insubstantial or insufficient; there may be substantial positive trends for some aspects of the } \\
\text { element but little or no progress for others; or the trends are positive in some geographical } \\
\text { regions but not in others); poor (little or no progress towards the element or movement away } \\
\text { from it; although there may be local, national or case-specific successes and positive trends } \\
\text { for some aspects, the overall global trend shows little or negative progress); or unknown } \\
\text { (insufficient information to score progress). Table partially adapted from refs. }{ }^{24,152 .}\end{array}$} \\
\hline
\end{tabular}

and freshwater environments. Moreover, $78.3 \%$ of known threatened species and more than half of all ecosystems on land and sea remained without adequate protection in 2019. A clear lesson from this assessment is that nations must expand area-based conservation efforts and better ensure that they contribute meaningfully to global goals for species and ecosystem conservation, which range from stopping extinction ${ }^{86}$ to keeping ecosystems intact ${ }^{87}$. The past decade has also shown that many protected areas are poorly managed (owing predominantly to chronic resource shortages), and that many Indigenous and community groups are inadequately or inequitably represented in land, water and sea conservation plans. In light of these lessons, we identify three urgent challenges that must be acted upon by governments, scientists, policy-makers and other stakeholders as they embark on the next decade of area-based conservation (Tables 2,3).

\section{Making OECMs count}

There are now expanding opportunities to formally recognize places outside state-run protected areas that can conserve biodiversity. In addition to protected areas that are governed privately ${ }^{88}$ and by Indigenous peoples ${ }^{84}$, other OECMs are being increasingly recognized. The importance of OECMs was formally recognized in Aichi Target 11 in 2010, but their guiding principles and criteria for identification were not agreed until November 2018 (Box 1). This delay probably contributed to OECMs being overlooked in most national biodiversity policies and strategies over the past decade. With a formal definition now agreed ${ }^{89}$, nations and managing bodies look set to operationalize OECMs more rapidly. The challenge now for the conservation community is to ensure that OECMs contribute meaningfully to biodiversity conservation.

OECMs could help to address representation shortfalls in the global protected-area estate. One recent study has shown that 566 unprotected
KBAs are at least partly covered by one or more potential OECMs ${ }^{4}$, andcompared with nationally designated protected areas-OECMs may prove to be more socially acceptable in productive land- and seascapes (which are hotspots for poorly protected threatened species ${ }^{10,11}$ ). Recognizing OECMs in inshore marine habitats, farmlands and managed forests could also enhance the connectivity of area-based conservation efforts, providing that natural ecological functions can be restored and maintained in such areas ${ }^{90,91}$. Wider recognition of OECMs should also help to make area-based conservation management more equitable, as they are managed by and for the benefit of a diverse set of actors. A recent study showed that lands managed by Indigenous communities in Australia, Brazil and Canada support concentrations of vertebrate species similar to those inside nationally designated protected areas $^{92}$, which exemplifies the importance of working with Indigenous peoples to recognize OECMs in their territories.

However, to deliver on the potential of OECMs, governments, private industry and the conservation community must immediately mobilize support for OECMs to overcome the issues that are faced by many protected areas, including inadequate reporting and resourcing. A reporting platform for OECMs ${ }^{8}$ was released in December 2019 and has the potential to make assessments of progress towards the successor of Aichi Target 11 more accurate, if countries make use of it. The success of OECMs will also depend on governments and conservation actors upholding human rights and social safeguards, particularly in Indigenous and community areas. In cases in which meeting OECM criteria will require some adaptation to livelihoods, great care must be taken to develop alternative livelihood opportunities that deliver tangible benefits to resource users ${ }^{93}$. Alternative livelihood schemes must also be mindful to retain the biodiversity benefits of OECMs ${ }^{94}$.

\section{Tracking the increasing dynamism of area-based conservation}

Recent studies have shown that protected areas are more dynamic in space and time than previously thought ${ }^{9}$. Decisions to remove, shrink or relax protected areas are poorly documented, which makes it difficult to assess which ecosystems are most susceptible to such dynamics or how these changes affect the overall quality of area-based conservation networks. The challenge for the conservation community is to have protected area dynamics reported more transparently, especially when they compromise biodiversity outcomes.

Many removals from the protected-area estate can be attributed to 'protected area downgrading, downsizing and degazettement' (PADDD) events. More than 1,500 PADDD events affected, in total, over one-third of the protected area network in Australia $\left(416,740 \mathrm{~km}^{2}\right)$ between 1997 and $2014^{95}$. Moreover, 23 PADDD events have affected natural World Heritage sites (protected areas with 'outstanding universal value', such as the Virunga, Serengeti and Yosemite National Parks) ${ }^{96}$. PADDD events can accelerate forest loss and fragmentation ${ }^{97}$, and most (62\%) are associated with activities that are in stark conflict with biodiversity conservation, including industrial-scale resource extraction and infrastructure development ${ }^{98}$. Potentially of greatest concern are the many PADDD events that are going undocumented, particularly in marine systems ${ }^{99}$ and on private lands ${ }^{100}$.

To improve the transparency of area-based conservation decisions, we encourage governments and the conservation community to engage more with global PADDD tracking platforms (for example, www.padddtracker.org). We also believe that integrating PADDD tracking data with existing area-based conservation databases (for example, the World Database on Protected Areas ${ }^{7}$ ) would vastly improve their utility and aid global reporting. Dynamism in area-based conservation could signal attempts to expand or enhance protected areas, either through improved resourcing and management ${ }^{101,102}$ or by enacting more restrictive regulations ${ }^{103}$. As such, there is also a clear need to better incentivize and track the continuum of changes to protected areas that can improve their ability to conserve biodiversity. We suggest that such changes be characterized collectively as 'protected area gazettement, expansion 
Table 3 | Acting on key challenges to improve progress towards targets for area-based conservation in the twenty-first century

\begin{tabular}{|c|c|c|}
\hline & Challenges to improve progress & Potential actions to address challenges \\
\hline $\begin{array}{l}\text { Immediate discrete } \\
\text { priorities }\end{array}$ & $\begin{array}{l}\text { To make the dynamism of area-based } \\
\text { conservation more transparent } \\
\text { To make OECMs contribute substantively to } \\
\text { biodiversity conservation } \\
\text { To introduce more impact-orientated } \\
\text { evaluation of area-based conservation }\end{array}$ & $\begin{array}{l}\text { Use PADDD tracking platforms and integrate with WDPA } \\
\text { Better track PAGEE events } \\
\text { Engage with OECM reporting platforms } \\
\text { Mobilize support for OECMs to overcome reporting and resourcing issues } \\
\text { Ensure that OECMs are managed by a diverse set of actors } \\
\text { Collect better temporal biodiversity data, including through citizen science initiatives } \\
\text { Make robust impact evaluation a standard reporting requirement }\end{array}$ \\
\hline $\begin{array}{l}\text { Overarching } \\
\text { preconditions }^{1}\end{array}$ & $\begin{array}{l}\text { To secure adequate resourcing } \\
\text { To be climate-smart } \\
\text { To make biodiversity conservation mainstream }\end{array}$ & $\begin{array}{l}\text { Fund the contribution of area-based conservation to national economies } \\
\text { Better harness industry and philanthropic contributions } \\
\text { Safeguard ecological integrity } \\
\text { Use decision-support tools to make robust decisions } \\
\text { Adopt a bold overarching goal for biodiversity } \\
\text { Adopt biodiversity accounting protocols that align compensation with desired } \\
\text { trajectories for imperilled species or ecosystems }\end{array}$ \\
\hline
\end{tabular}

${ }^{1}$ Overarching preconditions require action by governments to ensure the long-term success of area-based conservation strategies.

and enhancement' (PAGEE) events. Clear, transparent tracking around both PADDD and PAGEE events will ensure we address-and do not exacerbate-current shortfalls in area-based conservation.

\section{Outcome-orientated evaluation of area-based conservation}

The numerous approaches that have been developed to evaluate area-based conservation efforts all have merit, but the conservation community remains too reliant on types of evaluation that focus on management inputs or threat reduction ${ }^{104}$ (Table 1). Adopting evaluation techniques that more effectively capture the biodiversity and socio-economic outcomes of area-based conservation is currently a substantial challenge.

The Global Database on Protected Area Management Effectiveness provides information on many protected area processes, including the existence of a management plan or the adequacy of law enforcement activities ${ }^{105}$. Yet the majority of the methodologies of the Global Database on Protected Area Management Effectiveness were not developed to quantify the effects of protected area management activities on species and ecosystems ${ }^{105}$, and therefore cannot be used to evaluate progress towards the effective conservation of biodiversity. High-resolution maps of ecological change across land- and seascapes, including forest cover change $\mathrm{e}^{106}$ and changes in cumulative human pressure ${ }^{107,108}$, enable more outcome-orientated conservation evaluations. But ecological changes across land- and seascapes do not always explain local biodiversity patterns ${ }^{109}$. The temporal resolution of cumulative human-pressure mapping also lags behind that of forest-cover mapping efforts, and some maps of human pressure are at spatial resolutions (for example, $77 \mathrm{~km}^{2}$ (ref. $\left.{ }^{108}\right)$ ) that preclude assessments of many small $\left(<1 \mathrm{~km}^{2}\right)$ - but crucially important ${ }^{110}$ - protected areas.

To make area-based conservation evaluations more outcomeorientated, we suggest making robust outcome evaluation techniques-both ex ante to help to site areas ${ }^{111}$ and ex post to report on outcomes $^{112}-$ a standard reporting requirement for all organizations that are involved in area-based conservation. Conservation agencies must then better fund long-term and well-designed biodiversity monitoring programmes. It will be especially important for such programmes to monitor control sites that match protected areas in terms of ecological and anthropogenic conditions, so as to isolate any confounding effects ${ }^{113,114}$. We also encourage governments and communities to engage more with citizen science initiatives that use techniques such as camera traps, drones and acoustic monitors to increase the coverage and frequency of biodiversity data ${ }^{115}$. Combining advances in remote sensing and field campaigns (for example, the Biomass Earth Explorer of the European Space Agency) with in situ reporting of protected area management capacity and biodiversity trends (for example, using the Spatial Monitoring and Reporting Tool (SMART) could also make outcome evaluations much more accurate and reliable.

\section{Future-proofing area-based conservation}

Although the three challenges already discussed are immediate priorities, broader policy changes can ensure that area-based conservation can contribute meaningfully to longer-term goals held by the CBD: namely, that 'by 2050, biodiversity is valued, conserved, restored and widely used, maintaining ecosystem services, sustaining a healthy planet and delivering benefits essential for all people $\mathrm{e}^{\prime 16}$ (Tables 2, 3). In this final section, we outline a set of necessary pre-conditions-adequate financing, being climate-smart and mainstreaming biodiversity across national policy frameworks - that require action by governments now to ensure the long-term success of area-based conservation strategies.

\section{Secure adequate financing}

The global funding available for species protection has more than halved in the past two decades, from approximately US $\$ 200$ million per year in the 2000 s to less than US $\$ 100$ million per year in the $2010 \mathrm{~s}^{117}$. The costs associated with expanding area-based conservation efforts compound resource shortfalls at existing sites. One estimate suggests that protecting and effectively managing a terrestrial protected-area network that is more taxonomically comprehensive that the current network would cost US $\$ 76.1$ billion annually ${ }^{118}$. As such, a conservative estimate of the current financial shortfall for area-based conservation probably exceeds the multi-billion dollar mark. This shortfall is unlikely to be fully addressed in the coming decade, but reducing it must become an immediate priority for governments and private industry.

Current and future resourcing needs could be met if the contribution of area-based conservation to national economies was adequately recognized. The direct value generated by visits to protected areas is valued at US $\$ 600$ billion per year ${ }^{119}$. Governments must therefore better account for the contribution of area-based conservation efforts to national economies. When budgeting for area-based conservation, we suggest that governments use predictive measures of funding requirements and effects ${ }^{120}$, and that they consider the under-appreciated cost-saving benefits of effective biodiversity conservation. For example, it would be useful to compare the costs arising from the socio-economic devastation caused by zoonotic diseases such as severe acute respiratory syndrome or coronavirus disease 2019 with those needed to effectively manage area-based conservation networks in a way that reduces supply to illegal wildlife markets ${ }^{121,122}$. There is also an urgent need to better harness industry and philanthropic contributions to area-based conservation, through-for example-improved 
funding guidelines that ensure that the involvement of private interests does not compromise the siting or management of area-based conservation $^{123-125}$.

\section{Being climate-smart}

Anthropogenic climate change will become an increasingly strong mediator of the success of area-based conservation this decade $\mathrm{e}^{126}$, with many predicted biological responses to climate change already underway ${ }^{127}$. A recent study showed that under a business-as-usual scenario for greenhouse gas emissions (Representative Concentration Pathway (RCP) 8.5), mean sea-surface temperatures within marine protected areas are projected to increase by $2.8^{\circ} \mathrm{C}$ by $2100^{128}$. We overlaid climate change projections under a more-moderate emissions scenario (RCP 4.5) on the terrestrial protected-area network and found that temperatures in the warmest quarter will increase on average by $2.9^{\circ} \mathrm{C}$ on protected land by 2050 , with higher increases occurring in European nations (Supplementary Fig. 2, Supplementary Table 12). We also found that by 2050 some biodiverse nations, including Suriname and Guyana, can expect 30-40\% less rainfall on protected land during dry months (Supplementary Fig. 3, Supplementary Table 13). Such changes in bioclimatic conditions are likely to markedly alter ecological networks ${ }^{129}$ and imperil some species and ecosystems ${ }^{130}$. Even the relatively moderate RCP 4.5 scenarios are likely to drive the elimination of most warm-water coral reefs by $2040-2050^{131}$.

There are now well-established ways to incorporate climate change into area-based conservation plans ${ }^{132}$, including safeguarding or-where possible-restoring the integrity of ecosystems around protected areas so as to ensure ecological connectivity ${ }^{133,134}$. Ensuring that managers have the knowledge and capacity to implement realistic climate adaptation policies is also paramount ${ }^{135}$. Greater enforcement of conservation regulations ${ }^{136}$ and accounting for human responses to climate change ${ }^{137}$ are also likely to enhance the climate resilience of area-based conservation efforts. However, targeting protected areas in sites in which bioclimatic changes may be small (refugia) must be done with caution, because predicted changes can be spatially discordant ${ }^{128}$ as can the biotic response. For example, only $3.5 \%$ of marine protected areas co-occur with refugia for both sea-surface temperature and oxygen concentration $^{128}$. In such cases, decision-support tools (for example, value-of-information analysis ${ }^{138}$ and systems modelling ${ }^{139}$ ) can evaluate the benefits of resolving uncertainty about ecological responses to climate change before implementing conservation action, and therefore lead to more-robust management decisions.

\section{Make biodiversity conservation mainstream}

No matter how well-sited, resourced or managed, area-based conservation can act only on a subset of threats to biodiversity persistence. The amelioration of large-scale distal threats requires other interventions that are triggered by broader land, water and sea management policies $^{140,141}$. China is the first major economy to formulate a national policy-known as the Ecological Redline Policy-that mandates municipality and provincial governments to establish biodiversity and ecosystem service assessments in land-use planning ${ }^{142}$. It is hoped that the Ecological Redline Policy extends to China's planned activities beyond their national boundaries-including the Belt and Road Initiative, which could affect many areas of critical conservation concern ${ }^{143}$. However, most national land, water and sea management policies are subservient to economic development ${ }^{144}$ or contain loopholes that lead to perverse environmental outcomes ${ }^{145}$. Governments must recognize that getting these policies right is essential and will ease the strain on area-based conservation strategies in the long term.

Two cross-cutting changes could improve the efficacy of national land, water and sea management policies. First, we suggest that nations adopt an overarching goal for biodiversity that is bold-to have a net positive effect on biodiversity, for example ${ }^{29}$-and then agree a set of socio-economic and environmental targets that can contribute proportionally to this overarching goal. Targets should then be made mutually conditional: environmental targets (for example, to protect $30 \%$ of land) cannot be considered met if progress towards socio-economic targets (for example, to eliminate incentives harmful to biodiversity) is found to be wanting. Improving biodiversity accounting protocols could also enhance the efficacy of land, water and sea management policies. One example of this is switching from biodiversity impact-offsetting protocols that simply displace conservation funding or entrench rates of biodiversity loss (for example, averted loss offsetting) to emerging protocols that align compensation with desired trajectories for imperilled species or ecosystems (for example, target-based compensation $)^{146}$.

\section{Conclusions}

Area-based conservation will remain the cornerstone of biodiversity conservation long into the twenty-first century, but governments have markedly underinvested in protected areas and OECMs and been weak in legally protecting them. In addition to addressing existing shortfalls, conservation organizations need to adopt more impact-orientated evaluation measures and promote governance and management equity. Organizations must also improve the transparency of decisions that result in spatial and resource dynamics, and ensure that OECMs can contribute meaningfully to biodiversity conservation. Finally, governments must future-proof area-based conservation by securing adequate financing, being climate-smart and mainstreaming biodiversity across environmental and socio-economic policies.

\section{Data availability}

The World Database on Protected Areas (http://www.protectedplanet. net) ${ }^{7}$, the World Database of KBAs (http://keybiodiversityareas.org) ${ }^{37}$, ecoregions on land ${ }^{31}$ and sea ${ }^{32,147}$, wilderness on land ${ }^{39}$ and sea ${ }^{38}$, geographical distributions of non-avian ${ }^{35}$ and avian ${ }^{148}$ threatened species and bioclimatic projection $s^{149}$ are publically available online. Maps of fisheries catch ${ }^{150}$, particulate organic carbon ${ }^{49}$ and dissolved organic carbon $^{50}$ export, and biomass and soil carbon ${ }^{44}$ can be obtained from their creators. Source data for Figs. 1-3, Supplementary Figs. 3, 4 and all Supplementary tables are available in an online digital repository at https://doi.org/10.5281/zenodo.3894431.

\section{Code availability}

Spatial analysis was conducted using ESRI ArcGIS Pro v.2.4.0. The workflow we used to process the World Database on Protected Areas is available in the Supplementary Information.

1. Watson, J. E. M., Dudley, N., Segan, D. B. \& Hockings, M. The performance and potential of protected areas. Nature 515, 67-73 (2014).

2. Dudley, N. Guidelines for Applying Protected Area Management Categories (IUCN, 2008).

3. Dudley, N. et al. The essential role of other effective area-based conservation measures in achieving big bold conservation targets. Glob. Ecol. Conserv. 15, e00424 (2018).

4. Donald, P. F. et al. The prevalence, characteristics and effectiveness of Aichi Target 11's "other effective area-based conservation measures"(OECMs) in Key Biodiversity Areas. Conserv. Lett. 12, 12659 (2019).

5. UN General Assembly. Transforming our World: The 2030 Agenda for Sustainable Development, 21 October 2015. A/RES/70/1 https://www.refworld.org/docid/57b6e3e44 html (accessed 11 November 2019).

6. Convention on Biological Diversity. COP 10 Decision X/2: Strategic Plan for Biodiversity 2011-2020. http://www.cbd.int/decision/cop/?id=12268 (2011).

7. UNEP-WCMC \& IUCN. World Database on Protected Areas (WDPA). https://www. protectedplanet.net/ (UNEP-WCMC, 2019).

8. UNEP-WCMC \& IUCN. World Database on Other Effective Area-based Conservation Measures (WD-OCEM). https://www.protectedplanet.net/c/ other-effective-area-based-conservation-measures (UNEP-WCMC, 2019).

9. Lewis, E. et al. Dynamics in the global protected-area estate since 2004. Conserv. Biol. 33, 570-579 (2019).

10. Klein, C. J. et al. Shortfalls in the global protected area network at representing marine biodiversity. Sci. Rep. 5, 17539 (2015). 


\section{Review}

11. Venter, O. et al. Bias in protected-area location and its effects on long-term aspirations of biodiversity conventions. Conserv. Biol. 32, 127-134 (2018).

12. Mouillot, D. et al. Global marine protected areas do not secure the evolutionary history of tropical corals and fishes. Nat. Commun. 7, 10359 (2016).

13. Butchart, S. H. M. et al. Shortfalls and solutions for meeting national and global conservation area targets. Conserv. Lett. 8, 329-337 (2015).

14. Christie, P. et al. Why people matter in ocean governance: incorporating human dimensions into large-scale marine protected areas. Mar. Policy 84, 273-284 (2017).

15. Zafra-Calvo, N. et al. Progress toward equitably managed protected areas in Aichi target 11: a global survey. Bioscience 69, 191-197 (2019). This is the first large review of how well protected areas satisfy social equity metrics.

16. Juffe-Bignoli, D. et al. Achieving Aichi biodiversity target 11 to improve the performance of protected areas and conserve freshwater biodiversity. Aquat. Conserv. 26, 133-151 (2016).

17. Maron, M., Simmonds, J. S. \& Watson, J. E. M. Bold nature retention targets are essential for the global environment agenda. Nat. Ecol. Evol. 2, 1194-1195 (2018).

18. Geldmann, J. et al. Changes in protected area management effectiveness over time: a global analysis. Biol. Conserv. 191, 692-699 (2015).

19. Di Minin, E. \& Toivonen, T. Global protected area expansion: creating more than paper parks. Bioscience 65, 637-638 (2015)

20. Gill, D. A. et al. Capacity shortfalls hinder the performance of marine protected areas globally. Nature 543, 665-669 (2017) This study compiles four years of data to assess capacity shortfalls and biodiversity outcomes from the management of 589 marine protected areas.

21. Coad, L. et al. Widespread shortfalls in protected area resourcing undermine efforts to conserve biodiversity. Front. Ecol. Environ. 17, 259-264 (2019).

22. Visconti, P. et al. Protected area targets post-2020. Science 364, 239-241 (2019).

23. Barnes, M. D., Glew, L., Wyborn, C. \& Craigie, I. D. Prevent perverse outcomes from global protected area policy. Nat. Ecol. Evol. 2, 759-762 (2018)

24. IPBES. Summary for Policymakers of the Global Assessment Report on Biodiversity and Ecosystem Services of the Intergovernmental Science-Policy Platform on Biodiversity and Ecosystem Services (IPBES secretariat, 2019).

This report assesses the status of biodiversity and ecosystem services, their impact on human well-being and the effectiveness of conservation interventions.

25. Dinerstein, E. et al. A global deal for nature: guiding principles, milestones, and targets. Sci. Adv. 5, eaaw2869 (2019).

26. Noss, R. F. et al. Bolder thinking for conservation. Conserv. Biol. 26, 1-4 (2012).

27. Wilson, E. O. Half-Earth: Our Planet's Fight for Life (Liveright, 2016).

28. O'Leary, B. C. et al. Effective coverage targets for ocean protection. Conserv. Lett. 9 398-404 (2016)

29. Bull, J. W. et al. Net positive outcomes for nature. Nat. Ecol. Evol. 4, 4-7 (2020).

30. Mace, G. M. et al. Aiming higher to bend the curve of biodiversity loss. Nat. Sustain. 1 448-451 (2018).

31. Dinerstein, E. et al. An ecoregion-based approach to protecting half the terrestrial realm Bioscience 67, 534-545 (2017).

32. Spalding, M. D. et al. Marine ecoregions of the world: a bioregionalization of coastal and shelf areas. Bioscience 57, 573-583 (2007)

33. UNEP-WCMC, IUCN \& NGS. Protected Planet Report 2018 (UNEP-WCMC, IUCN and NGS, 2018)

A biennial publication that reviews progress toward protected areas targets and goals.

34. Rodrigues, A. S. L. et al. Global gap analysis: priority regions for expanding the global protected-area network. Bioscience 54, 1092-1100 (2004).

35. IUCN. The IUCN Red List of Threatened Species. Version 2019-2 http://www.iucnredlist. org (accessed 10 September 2019) (2019).

36. IUCN. A Global Standard for the Identification of Key Biodiversity Areas. Version 1.0 (IUCN, 2016)

37. BirdLife International. World Database of Key Biodiversity Areas. www. keybiodiversityareas.org (accessed 20 June 2019) (2019).

38. Jones, K. R. et al. The location and protection status of Earth's diminishing marine wilderness. Curr. Biol. 28, 2506-2512 (2018)

39. Allan, J. R., Venter, O. \& Watson, J. E. M. Temporally inter-comparable maps of terrestrial wilderness and the last of the wild. Sci. Data 4, 170187 (2017)

40. Watson, J. E. M. et al. The exceptional value of intact forest ecosystems. Nat. Ecol. Evol. 2 599-610 (2018).

41. Di Marco, M., Ferrier, S., Harwood, T. D., Hoskins, A. J. \& Watson, J. E. M. Wilderness areas halve the extinction risk of terrestrial biodiversity. Nature 573, 582-585 (2019).

42. Martin, T. G. \& Watson, J. E. M. Intact ecosystems provide best defence against climate change. Nat. Clim. Chang. 6, 122-124 (2016)

43. Griscom, B. W. et al. Natural climate solutions. Proc. Natl Acad. Sci. USA 114, 11645-11650 (2017).

44. Soto-Navarro, C. et al. Mapping co-benefits for carbon storage and biodiversity to inform conservation policy and action. Phil. Trans. R. Soc. Lond. B 375, 20190128 (2020) This study combines multiple datasets to produce a new high-resolution map of global above- and belowground carbon stored in biomass and soil.

45. Dargie, G. C. et al. Age, extent and carbon storage of the central Congo Basin peatland complex. Nature 542, 86-90 (2017).

46. DeVries, T. \& Weber, T. The export and fate of organic matter in the ocean: new constraints from combining satellite and oceanographic tracer observations. Glob. Biogeochem. Cycles 31, 535-555 (2017)

47. Laws, E. A., D'Sa, E. \& Naik, P. Simple equations to estimate ratios of new or export production to total production from satellite-derived estimates of sea surface temperature and primary production. Limnol. Oceanogr. Methods 9, 593-601 (2011).

48. DeVries, T., Primeau, F. \& Deutsch, C. The sequestration efficiency of the biological pump. Geophys. Res. Lett. 39, L13601 (2012)

49. Henson, S. A., Sanders, R. \& Madsen, E. Global patterns in efficiency of particulate organic carbon export and transfer to the deep ocean. Glob. Biogeochem. Cycles 26, GB1028 (2012)
50. Roshan, S. \& DeVries, T. Efficient dissolved organic carbon production and export in the oligotrophic ocean. Nat. Commun. 8, 2036 (2017)

51. Lutz, M. J., Caldeira, K., Dunbar, R. B. \& Behrenfeld, M. J. Seasonal rhythms of net primary production and particulate organic carbon flux to depth describe the efficiency of biological pump in the global ocean. J. Geophys. Res. Oceans 112, C10011 (2007).

52. Magris, R. A. et al. Biologically representative and well-connected marine reserves enhance biodiversity persistence in conservation planning. Conserv. Lett. 11, e12439 (2018)

53. Mendenhall, C. D., Karp, D. S., Meyer, C. F. J., Hadly, E. A. \& Daily, G. C. Predicting biodiversity change and averting collapse in agricultural landscapes. Nature $\mathbf{5 0 9}$ 213-217 (2014).

54. Harrison, H. B. et al. Larval export from marine reserves and the recruitment benefit for fish and fisheries. Curr. Biol. 22, 1023-1028 (2012).

55. Johnson, D. W., Christie, M. R., Pusack, T. J., Stallings, C. D. \& Hixon, M. A. Integrating larval connectivity with local demography reveals regional dynamics of a marine metapopulation. Ecology 99, 1419-1429 (2018)

56. Saura, S., Bastin, L., Battistella, L., Mandrici, A. \& Dubois, G. Protected areas in the world's ecoregions: how well connected are they? Ecol. Indic. 76, 144-158 (2017).

57. Saura, S. et al. Global trends in protected area connectivity from 2010 to 2018 . Biol. Conserv. 238, 108183 (2019)

58. Endo, C. A. K., Gherardi, D. F. M., Pezzi, L. P. \& Lima, L. N. Low connectivity compromises the conservation of reef fishes by marine protected areas in the tropical South Atlantic. Sci. Rep. 9, 8634 (2019)

59. Bergseth, B. J., Gurney, G. G., Barnes, M. L., Arias, A. \& Cinner, J. E. Addressing poaching in marine protected areas through voluntary surveillance and enforcement. Nat. Sustain.1, 421-426 (2018).

This study uses a citizen science approach to estimate poaching rates inside 55 marine protected areas spanning seven countries.

60. Jones, K. R. et al. One-third of global protected land is under intense human pressure. Science 360, 788-791 (2018).

61. Costello, M. J. \& Ballantine, B. Biodiversity conservation should focus on no-take marine reserves: $94 \%$ of marine protected areas allow fishing. Trends Ecol. Evol. 30, 507-509 (2015).

62. Zupan, M. et al. Marine partially protected areas: drivers of ecological effectiveness. Front. Ecol. Environ. 16, 381-387 (2018).

63. Spracklen, B. D., Kalamandeen, M., Galbraith, D., Gloor, E. \& Spracklen, D. V. A global analysis of deforestation in moist tropical forest protected areas. PLOS ONE 10, e0143886 (2015).

64. Herrera, D., Pfaff, A. \& Robalino, J. Impacts of protected areas vary with the level of government: comparing avoided deforestation across agencies in the Brazilian Amazon. Proc. Natl Acad. Sci. USA 116, 14916-14925 (2019).

65. Negret, P. J. et al. Effects of spatial autocorrelation and sampling design on estimates of protected area effectiveness. Conserv. Biol. https://doi.org/10.1111/cobi.13522 (2020).

66. White, T. D. et al. Assessing the effectiveness of a large marine protected area for reef shark conservation. Biol. Conserv. 207, 64-71 (2017).

67. Giakoumi, S. \& Pey, A. Assessing the effects of marine protected areas on biological invasions: a global review. Front. Mar. Sci. 4, 49 (2017)

68. Geldmann, J., Manica, A., Burgess, N. D., Coad, L. \& Balmford, A. A global-level assessment of the effectiveness of protected areas at resisting anthropogenic pressures. Proc. Natl Acad. Sci. USA, 116, 23209-23215 (2019).

69. Gray, C. L. et al. Local biodiversity is higher inside than outside terrestrial protected areas worldwide. Nat. Commun. 7, 12306 (2016).

This controlled study shows how biodiversity outcomes from protected area management are mediated by different classes of land use.

70. Kerwath, S. E., Winker, H., Götz, A. \& Attwood, C. G. Marine protected area improves yield without disadvantaging fishers. Nat. Commun. 4, 2347 (2013).

71. Speed, C. W., Cappo, M. \& Meekan, M. G. Evidence for rapid recovery of shark populations within a coral reef marine protected area. Biol. Conserv. 220, 308-319 (2018).

72. Caselle, J. E., Rassweiler, A., Hamilton, S. L. \& Warner, R. R. Recovery trajectories of kelp forest animals are rapid yet spatially variable across a network of temperate marine protected areas. Sci. Rep. 5, 14102 (2015)

73. Emslie, M. J. et al. Expectations and outcomes of reserve network performance following re-zoning of the Great Barrier Reef marine park. Curr. Biol. 25, 983-992 (2015).

74. Campbell, S. J., Edgar, G. J., Stuart-Smith, R. D., Soler, G. \& Bates, A. E. Fishing-gear restrictions and biomass gains for coral reef fishes in marine protected areas. Conserv. Biol. 32, 401-410 (2018)

75. Mumby, P. J. et al. Trophic cascade facilitates coral recruitment in a marine reserve. Proc Natl Acad. Sci. USA 104, 8362-8367 (2007).

76. Boaden, A. E. \& Kingsford, M. J. Predators drive community structure in coral reef fish assemblages. Ecosphere 6, art46 (2015).

77. Lamb, J. B., Williamson, D. H., Russ, G. R. \& Willis, B. L. Protected areas mitigate diseases of reef-building corals by reducing damage from fishing. Ecology 96, 2555-2567 (2015).

78. Naidoo, R. et al. Evaluating the impacts of protected areas on human well-being across the developing world. Sci. Adv. 5, eaav3006 (2019)

79. Zafra-Calvo, N. et al. Towards an indicator system to assess equitable management in protected areas. Biol. Conserv. 211, 134-141 (2017).

80. Oldekop, J. A., Holmes, G., Harris, W. E. \& Evans, K. L. A global assessment of the social and conservation outcomes of protected areas. Conserv. Biol. 30, 133-141 (2016).

81. Giakoumi, S. et al. Revisiting "success" and "failure" of marine protected areas: a conservation scientist perspective. Front. Mar. Sci. 5, 223 (2018).

82. Edgar, G. J. et al. Global conservation outcomes depend on marine protected areas with five key features. Nature 506, 216-220 (2014).

83. Ban, N. C. et al. Well-being outcomes of marine protected areas. Nat. Sustain. 2, 524-532 (2019).

84. Corrigan, C. et al. Quantifying the contribution to biodiversity conservation of protected areas governed by indigenous peoples and local communities. Biol. Conserv. 227, 403-412 (2018) 
85. Schleicher, J., Peres, C. A., Amano, T., Llactayo, W. \& Leader-Williams, N. Conservation performance of different conservation governance regimes in the Peruvian Amazon. Sci. Rep. 7, 11318 (2017)

86. Hoffmann, M. et al. The difference conservation makes to extinction risk of the world's ungulates. Conserv. Biol. 29, 1303-1313 (2015).

87. Watson, J. E. M. et al. Set a global target for ecosystems. Nature 578, 360-362 (2020).

88. Stolton, S., Redford, K. H. \& Dudley, N. The Futures of Privately Protected Areas (IUCN, 2014).

89. IUCN WCPA. Guidelines for Recognising and Reporting Other Effective Area-based Conservation Measures (IUCN, 2019).

90. Shabtay, A., Portman, M. E., Manea, E. \& Gissi, E. Promoting ancillary conservation through marine spatial planning. Sci. Total Environ. 651, 1753-1763 (2019).

91. Banks-Leite, C. et al. Using ecological thresholds to evaluate the costs and benefits of set-asides in a biodiversity hotspot. Science 345, 1041-1045 (2014).

92. Schuster, R., Germain, R. R., Bennett, J. R., Reo, N. J. \& Arcese, P. Vertebrate biodiversity on indigenous-managed lands in Australia, Brazil, and Canada equals that in protected areas. Environ. Sci. Policy 101, 1-6 (2019).

93. Bennett, N. J. \& Dearden, P. From measuring outcomes to providing inputs: governance, management, and local development for more effective marine protected areas. Mar. Policy 50, 96-110 (2014).

94. Suchley, A. \& Alvarez-Filip, L. Local human activities limit marine protection efficacy on Caribbean coral reefs. Conserv. Lett. 11, e12571 (2018).

95. Cook, C. N., Valkan, R. S., Mascia, M. B. \& McGeoch, M. A. Quantifying the extent of protected-area downgrading, downsizing, and degazettement in Australia. Conserv. Biol. 31, 1039-1052 (2017).

96. Qin, S. et al. Protected area downgrading, downsizing, and degazettement as a threat to iconic protected areas. Conserv. Biol. 33, 1275-1285 (2019).

97. Forrest, J. L. et al. Tropical deforestation and carbon emissions from protected area downgrading, downsizing, and degazettement (PADDD). Conserv. Lett. 8, 153-161 (2015).

98. Golden Kroner, R. E. et al. The uncertain future of protected lands and waters. Science 364, 881-886 (2019).

\section{This study compiled data that are available globally on PADDD events.}

99. Roberts, K. E., Valkan, R. S. \& Cook, C. N. Measuring progress in marine protection: a new set of metrics to evaluate the strength of marine protected area networks. Biol. Conserv. 219, 20-27 (2018).

100. De Vos, A., Clements, H. S., Biggs, D. \& Cumming, G. S. The dynamics of proclaimed privately protected areas in South Africa over 83 years. Conserv. Lett. 12, e12644 (2019).

101. Costelloe, B. et al. Global biodiversity indicators reflect the modeled impacts of protected area policy change. Conserv. Lett. 9, 14-20 (2016).

102. Pringle, R. M. Upgrading protected areas to conserve wild biodiversity. Nature 546, 91-99 (2017).

103. Kuempel, C. D., Adams, V. M., Possingham, H. P. \& Bode, M. Bigger or better: the relative benefits of protected area network expansion and enforcement for the conservation of an exploited species. Conserv. Lett. 11, e12433 (2018).

104. Adams, V. M., Barnes, M. \& Pressey, R. L. Shortfalls in conservation evidence: moving from ecological effects of interventions to policy evaluation. One Earth 1, 62-75 (2019).

105. Coad, L. et al. Measuring impact of protected area management interventions: current and future use of the global database of protected area management effectiveness. Phil. Trans. R. Soc. Lond. B 370, 20140281 (2015).

106. Hansen, M. C. et al. High-resolution global maps of 21 st-century forest cover change. Science 342, 850-853 (2013).

107. Venter, O. et al. Sixteen years of change in the global terrestrial human footprint and implications for biodiversity conservation. Nat. Commun. 7, 12558 (2016).

108. Geldmann, J., Joppa, L. N. \& Burgess, N. D. Mapping change in human pressure globally on land and within protected areas. Conserv. Biol. 28, 1604-1616 (2014).

109. Wilkie, D. S., Bennett, E. L., Peres, C. A. \& Cunningham, A. A. The empty forest revisited. Ann. NY Acad. Sci. 1223, 120-128 (2011).

110. Volenec, Z. M. \& Dobson, A. P. Conservation value of small reserves. Conserv. Biol. 34 66-79 (2020)

111. Nicholson, E. et al. Scenarios and models to support global conservation targets. Trends Ecol. Evol. 34, 57-68 (2019).

112. Maron, M., Rhodes, J. R. \& Gibbons, P. Calculating the benefit of conservation actions Conserv. Lett. 6, 359-367 (2013).

113. Schleicher, J. et al. Statistical matching for conservation science. Conserv. Biol. 34, 538-549 (2019).

114. Ferraro, P. J. Counterfactual thinking and impact evaluation in environmental policy. New Dir. Eval. 2009, 75-84 (2009).

115. Chandler, M. et al. Contribution of citizen science towards international biodiversity monitoring. Biol. Conserv. 213, 280-294 (2017).

116. Convention on Biological Diversity. Long-Term Strategic Directions to the 2050 Vision for Biodiversity, Approaches to Living in Harmony with Nature and Preparation for the Post-2020 Global Biodiversity Framework. www.cbd.int/decision/cop?id=12268 (2018).

117. Secretariat of the Convention on Biological Diversity. Global Biodiversity Outlook 4 (Secretariat of the Convention on Biological Diversity, 2014).

118. McCarthy, D. P. et al. Financial costs of meeting global biodiversity conservation targets: current spending and unmet needs. Science 338, 946-949 (2012).

119. Balmford, A. et al. Walk on the wild side: estimating the global magnitude of visits to protected areas. PLoS Biol. 13, e1002074 (2015).

120. Waldron, A. et al. Reductions in global biodiversity loss predicted from conservation spending. Nature 551, 364-367 (2017).

121. Murray, K. A., Allen, T., Loh, E., Machalaba, C. \& Daszak, P. Emerging Viral Zoonoses from Wildlife Associated with Animal-Based Food Systems: Risks and Opportunities (Springer, 2016).

122. Dobson, A.P. et al. Ecology and economics for pandemic prevention. Science 369, 379-381 (2020).

123. Burmester, B. Upgrading or unhelpful? Defiant corporate support for a marine protected area. Mar. Policy 63, 206-212 (2016).
124. Larson, E. R., Howell, S., Kareiva, P. \& Armsworth, P. R. Constraints of philanthropy on determining the distribution of biodiversity conservation funding. Conserv. Biol. 30 , 206-215 (2016).

125. Smith, T. et al. Biodiversity means business: reframing global biodiversity goals for the private sector. Conserv. Lett. 13, e12690 (2019).

126. Elsen, P. R., Monahan, W. B., Dougherty, E. R. \& Merenlender, A. M. Keeping pace with climate change in global terrestrial protected areas. Sci. Adv. 6, eaay0814 (2020).

127. Poloczanska, E. S. et al. Global imprint of climate change on marine life. Nat. Clim. Chang. 3, 919-925 (2013).

128. Bruno, J. F. et al. Climate change threatens the world's marine protected areas. Nat. Clim. Chang. 8, 499-503 (2018).

129. Schleuning, M. et al. Ecological networks are more sensitive to plant than to animal extinction under climate change. Nat. Commun. 7, 13965 (2016).

130. Bonnot, T. W., Cox, W. A., Thompson, F. R. \& Millspaugh, J. J. Threat of climate change on a songbird population through its impacts on breeding. Nat. Clim. Chang. 8, 718-722 (2018).

131. Hoegh-Guldberg, O., Poloczanska, E. S., Skirving, W. \& Dove, S. Coral reef ecosystems under climate change and ocean acidification. Front. Mar. Sci. 4, 158 (2017).

132. Jones, K. R., Watson, J. E. M., Possingham, H. P. \& Klein, C. J. Incorporating climate change into spatial conservation prioritisation: a review. Biol. Conserv. 194, 121-130 (2016).

133. Green, A. L. et al. Larval dispersal and movement patterns of coral reef fishes, and implications for marine reserve network design. Biol. Rev. Camb. Philos. Soc. 90, 1215-1247 (2015)

134. Krueck, N. C. et al. Incorporating larval dispersal into MPA design for both conservation and fisheries. Ecol. Appl. 27, 925-941 (2017).

135. van Kerkhoff, L. et al. Towards future-oriented conservation: managing protected areas in an era of climate change. Ambio 48, 699-713 (2019).

136. Ling, S. D. \& Johnson, C. R. Marine reserves reduce risk of climate-driven phase shift by reinstating size- and habitat-specific trophic interactions. Ecol. Appl. 22, 1232-1245 (2012).

137. Maxwell, S. L., Venter, O., Jones, K. R. \& Watson, J. E. M. Integrating human responses to climate change into conservation vulnerability assessments and adaptation planning. Ann. NY Acad. Sci. 1355, 98-116 (2015)

138. Bennett, J. R. et al. When to monitor and when to act: value of information theory for multiple management units and limited budgets. J. Appl. Ecol. 55, 2102-2113 (2018).

139. Burgass, M. J., Halpern, B. S., Nicholson, E. \& Milner-Gulland, E. J. Navigating uncertainty in environmental composite indicators. Ecol. Indic. 75, 268-278 (2017).

140. Bennett, J. R. et al. Polar lessons learned: long-term management based on shared threats in Arctic and Antarctic environments. Front. Ecol. Environ. 13, 316-324 (2015).

141. Hughes, T. P. et al. Global warming and recurrent mass bleaching of corals. Nature $\mathbf{5 4 3}$, 373-377 (2017).

142. Bai, Y. et al. Developing China's ecological redline policy using ecosystem services assessments for land use planning. Nat. Commun. 9, 3034 (2018).

143. Hughes, A. C. Understanding and minimizing environmental impacts of the belt and road initiative. Conserv. Biol. 33, 883-894 (2019).

144. Alamgir, M. et al. High-risk infrastructure projects pose imminent threats to forests in Indonesian Borneo. Sci. Rep. 9, 140 (2019).

145. Azevedo, A. A. et al. Limits of Brazil's forest code as a means to end illegal deforestation. Proc. Natl Acad. Sci. USA 114, 7653-7658 (2017).

146. Simmonds, J. S. et al. Moving from biodiversity offsets to a target-based approach for ecological compensation. Conserv. Lett. 13, e12695 (2020).

147. Spalding, M. D., Agostini, V. N., Rice, J. \& Grant, S. M. Pelagic provinces of the world: a biogeographic classification of the world's surface pelagic waters. Ocean Coast. Manage. 60, 19-30 (2012)

148. NatureServe. Bird Species Distribution Maps of the World (BirdLife International, 2018).

149. Hijmans, R. J., Cameron, S. E., Parra, J. L., Jones, P. G. \& Jarvis, A. Very high resolution interpolated climate surfaces for global land areas. Int. J. Climatol. 25, 1965-1978 (2005).

150. Pauly, D. et al. Sea Around Us Concepts, Design and Data. www.seaaroundus.org (2020).

151. Ferraro, P. J. \& Pressey, R. L. Measuring the difference made by conservation initiatives: protected areas and their environmental and social impacts. Phil. Trans. R. Soc. Lond. B 370, 20140270 (2015).

152. Díaz, S. et al. Pervasive human-driven decline of life on Earth points to the need for transformative change. Science 366, eaax3100 (2019).

Acknowledgements We thank B. Williams, R. Venegas, S. Henson and S. Roshan for assisting with some of the analytical components of this Review. We also thank H. C. Jonas, P. Langhammer and those that attended the CBD's Thematic Workshop on Area-based Conservation Measures in Montreal in November 2019 for thoughts and discussion around this manuscript.

Author contributions S.L.M. compiled and analysed the data, S.L.M and J.E.M.W. designed the Review and drafted the manuscript, and all authors made substantive revisions to the work.

Competing interests The authors declare no competing interests.

Additional information

Supplementary information is available for this paper at https://doi.org/10.1038/s41586-020-

2773-z.

Correspondence and requests for materials should be addressed to S.L.M.

Peer review information Nature thanks Mathew Williams and the other, anonymous, reviewer(s) for their contribution to the peer review of this work.

Reprints and permissions information is available at http://www.nature.com/reprints. Publisher's note Springer Nature remains neutral with regard to jurisdictional claims in published maps and institutional affiliations.

(c) Springer Nature Limited 2020 